\title{
SOCIOECONOMIC ANALYSIS OF HYDROPONIC FODDER PRODUCTION IN SELECTED AREAS OF BANGLADESH: PROSPECTS AND CHALLENGES
}

\author{
M.T. Uddin" and A.R. Dhar \\ Department of Agricultural Economics, Bangladesh Agricultural University \\ Mymensingh-2202, Bangladesh
}

\begin{abstract}
The study was conducted to assess the prospects and challenges of hydroponic fodder production in Bangladesh. A total of 40 farmers were selected purposively from Kishoregonj and Jashore districts as sample for the study. A combination of descriptive, mathematical and statistical techniques was used to analyze the data. The findings of the study revealed that average household and farm size of the farmers were 5.0 persons and 0.48 hectare, respectively. Average annual income of the farmers was Tk. 92312, of which $56.1 \%$ income was from farming activities and $43.9 \%$ income was from non-farming activities. Majority of the technology adopting farmers $(35.8 \%$ farmers) were within the late majority group. Profitability analysis showed that net return and benefit cost ratio of hydroponic fodder production were Tk. 5400 per decimal and 1.82, respectively. Farm size, farming experience, training and extension contact had significant impact on farmers' adoption of hydroponic fodder production technology. Nutritional quality of fodder, high installation cost, medicinal value for human consumption and sensitivity to temperature were the major strength, weakness, opportunity and threat of hydroponic fodder, respectively. This fodder production technology is sustainable from the perspectives of energy use, environmental safety, economic viability and social/political equity. The study recommended that input support (especially seed), motivation, training programmes and extension services by different government and non-government organizations should be properly organized and implemented in town and water logging areas to raise the farmers' awareness for the adoption of hydroponic fodder production technology.
\end{abstract}

Keywords: Adoption, hydroponic fodder, profitability, prospects and challenges, sustainability

*Corresponding author email: tajbau@yahoo.com 


\section{INTRODUCTION}

Bangladesh is densely populated country with limited land resources where livestock gets very small places for grazing. It is important to serve green grass for getting increased productivity from livestock. The scarcity of animal feed and fodder has been identified as major constraint for the development of livestock in Bangladesh. Poor quality roughages having deficiencies in fermentable carbohydrates, protein, minerals and vitamins yield lower milk and meat of the animals (Migwi, 1997). At present, about $83 \%$ of the total cultivable land is used for cereal crops, where only $0.10 \%$ for cultivation of fodder crops (BBS, 2015). As a result, animal fodder shortage is aggravating day by day and recently it has emerged as an acute problem for rearing livestock in Bangladesh.

In natural conditions, soil acts as a mineral nutrient reservoir but the soil itself is not essential to plant growth. When the mineral nutrients in the soil are dissolved in water, plant roots are able to absorb them. When the required mineral nutrients are introduced into a plant's water supply artificially, soil is no longer required for the plant to thrive. Almost any terrestrial plant can grow like this. This method of growing plants using mineral nutrient solutions, in water, without soil is known as hydroponics. It requires just $480 \mathrm{sq}$. $\mathrm{ft}$ area to produce $1000 \mathrm{~kg}$ every day against 530 acres of land under conventional system saving water by $95 \%$ (Jemimah et al., 2015).

It is possible by hydroponic techniques to achieve better than normal farm production, immune to natural weather variations, as well as organic and more nutritive, in just about $5 \%$ of the space and $5 \%$ of the irrigation water. Hydroponic fodder production requires only about $2-3 \%$ of that water used under field conditions to produce the same amount of fodder (Al-Karaki and Al-Hashimi, 2012). There are two chief merits of the soil-less cultivation of plants: $1^{\text {st }}$, hydroponics may potentially produce much higher crop yields; and $2^{\text {nd }}$, hydroponics can be used in places where in-ground agriculture or gardening is not possible.

In Bangladesh, the demand for green fodder is increasing on the account of diversified uses of agricultural residues. Adequate attention is not being given to the production of fodder crops due to increasing pressure on land for production of food grains, oil seeds and pulses. In order to meet this increasing demand for green fodder, the next best alternative is to produce hydroponics fodder to supplement the meager pasture resources. Under this system, grass is grown without soil and the technology has been used in the developed countries for a long time. The most common sprouting crop is barley; although alfalfa, clover, corn, cow peas, oats, sorghum and wheat are possible grains to grow fodder. Determining the best forage crop is an important matter in producing highest fodder yield and quality and at the same time considering the economic dimensions in the process of hydroponic green fodder production by saving of seeds costs (Al-Karaki and Al-Hashimi, 2012). 
Hydroponic grass is economically more lucrative to many dairy farmers because of its high productivity, and non-susceptibility to diseases and infections. The grasses that grow in open fields sometimes causes diarrhoea and other diseases to the animals. The seed germination rate in this system is approximately 98 percent. The fodder produced through hydroponic system can be stored for up to 10 days. An indoor facility with a hydroponic fodder unit can provide with enough green grass to meet the nutrition needs of the animals. Some dairy proprietors in India have started growing grass in indoor facilities. The technology is quite simple and easy (UNB, 2017). Fodders grown in this system are more nutritious, rich in minerals and micronutrients, and also germ-free, and they could increase milk production by up to 15 percent at a dairy farm (Pramanik, 2017).

Importance of such farming technology has been portrayed in a good number of literatures. A reticent effort has been made here to appraise the previous research studies which are: Islam et al. (2016) carried out a study on the effect of seed rate and water level on production and chemical analysis of hydroponic fodder in Bangladesh and found that high production performances and nutritive value can be found by cultivating hydroponic fodder using two seeds (maize and wheat) in the housing condition; Salam et al. (2014) examined the feasibility of tomato production using different substrates in aquaponic system in Bangladesh and concluded that the gravels substrate gave the highest tomato production than the brick lets and gravels mixed with saw dust substrate; Islam et al. (2013) conducted a study on cost-return analysis of fodder production in selected areas of Bangladesh and declared that the BCR was the highest (2.18) in Jashore district and the lowest (2.18) in Kurigram district for fodder producer cum seller; Naik et al. (2013) studied on low cost devices for hydroponics fodder production in Goa, India and revealed that hydroponics fodder can be produced in low cost green houses with locally available or homegrown grains; Saha (2010) focused on soilless cultivation for landless people as an alternative livelihood practice through indigenous hydroponic agriculture in floodprone Bangladesh and demonstrated that farmers can use their submerged lands for crop production where plants can be grown on the water in a bio-land or floating bed of water-hyacinth, algae and other plant residues.

It is evident from the above discussion that no empirical study has been conducted yet on prospects and challenges of hydroponic fodder production in Bangladesh. Thus, there exists a scope to identify the present adoption scenario and production practice of hydroponic fodder in Bangladesh. Research on socioeconomic aspects of hydroponic fodder production in Bangladesh is scarce and many policy level questions still are remained unanswered. Therefore, the study is highly relevant to the national goal of the government stated in the National Agriculture Policy. The specific objectives of the study are: i) to document the socioeconomic status of hydroponic fodder producers in Bangladesh; ii) to estimate the profitability of hydroponic fodder production in the study area; iii) to examine the factors affecting adoption of hydroponic fodder technology by the farmers; and iv) to address the 
prospects and challenges as well as suggest policy recommendations for sustainable hydroponic fodder production in Bangladesh.

\section{MATERIALS AND METHODS}

\section{Study area, sample size and data acquisition methods}

The study was conducted at different villages of Kishoregonj and Jashore districts. A total of 40 sample farmers were interviewed using pre-tested questionnaire. Purposive random sampling technique was followed to select the sample farmers. Moreover, key informant interviews (KII) were also performed in Dhaka, Gazipur and Narayangonj for collecting the necessary information. Secondary data sources like reports, publications, handouts, etc. relevant with this study were also consulted.

\section{Analytical techniques}

For analyzing the data, a combination of descriptive (sum, averages, percentages, etc.), mathematical and statistical techniques were used to achieve the objectives and to get the meaningful result.

\section{Profitability analysis}

Profitability of hydroponic fodder production was measured in terms of gross return, gross margin, net return, and benefit cost ratio (undiscounted). The formula needed for the calculation of profitability is discussed as follows:

\section{Gross return (GR)}

Gross return was calculated by multiplying the total volume of output by the price in the harvesting period (Dillon and Hardaker, 1993). The equation was as follows:

$$
\mathrm{GR}=\mathrm{X}_{\mathrm{mp}} \mathrm{P}_{\mathrm{mp}}+\mathrm{X}_{\mathrm{bp}} \mathrm{P}_{\mathrm{bp}}
$$

Where,

$$
\begin{aligned}
& \mathrm{X}_{\mathrm{mp}}=\text { Yield of main product }(\mathrm{kg} \mathrm{decimal} \\
& \left.\mathrm{P}_{\mathrm{mp}}^{-1}\right) \\
& \mathrm{X}_{\mathrm{bp}}=\text { Price of main product }\left(\mathrm{Tk} \cdot \mathrm{kg}^{-1}\right) ; \\
& \mathrm{P}_{\mathrm{bp}}=\text { Price of by-product }\left(\mathrm{Tk} \cdot \mathrm{kg}^{-1}\right)
\end{aligned}
$$

\section{Gross margin (GM)}

Gross margin was calculated by the difference between gross return and total variable cost. The following equation was used to calculate GM:

$$
\mathrm{GM}=\mathrm{GR}-\Sigma \mathrm{C}_{\mathrm{v}}
$$

Where,

$$
\begin{aligned}
\mathrm{GR} & =\text { Gross return }\left(\mathrm{Tk} \cdot \text { decimal }^{-1}\right) ; \text { and } \\
\Sigma \mathrm{C}_{\mathrm{v}} & =\text { Total variable cost }\left(\mathrm{Tk} \cdot \text { decimal }^{-1}\right) .
\end{aligned}
$$




\section{Net return (NR)}

Net return was calculated by deducting all costs (variable and fixed) from the gross return. The following algebraic form of NR was used for estimation:

$\mathrm{NR}=\mathrm{GR}-\Sigma \mathrm{C}_{\mathrm{v}}-\Sigma \mathrm{C}_{\mathrm{f}}$

Where,

GR $=$ Gross return $\left(\mathrm{Tk} \cdot\right.$ decimal $\left.^{-1}\right)$;

$\Sigma \mathrm{C}_{\mathrm{v}}=$ Total variable cost $\left(\mathrm{Tk} \cdot\right.$ decimal $\left.^{-1}\right)$; and

$\Sigma \mathrm{C}_{\mathrm{f}}=$ Total fixed cost $\left(\mathrm{Tk} \cdot\right.$ decimal $\left.^{-1}\right)$.

\section{Benefit cost ratio (BCR)}

Benefit cost ratio $(\mathrm{BCR})$ is a relative measure which is used to compare the return per unit of cost. BCR was estimated as a ratio of gross return to gross cost. The formula used for calculating BCR (undiscounted) was as follows:

$\mathrm{BCR}=\mathrm{GR} \div \mathrm{GC}$

Where,

$\mathrm{GR}=$ Gross return $\left(\mathrm{Tk}\right.$. decimal $\left.^{-1}\right)$; and

$\mathrm{GC}=$ Gross cost (i.e. $\left.\Sigma \mathrm{C}_{\mathrm{v}}+\Sigma \mathrm{C}_{\mathrm{f}}\right)\left(\right.$ Tk. decimal $\left.^{-1}\right)$.

\section{Logit model}

In order to identify the factors influencing adoption of hydroponic fodder technology by the farmers, the following logistic regression analysis (i.e. Logit model) was used (Gujarati, 2003):

$$
\begin{array}{ll} 
& \mathrm{K}_{\mathrm{i}}=\ln \left[\mathrm{P}_{\mathrm{i}} \div\left(1-\mathrm{P}_{\mathrm{i}}\right)\right]=\beta_{0}+\beta_{1} \mathrm{X}_{1}+\beta_{2} \mathrm{X}_{2}+\beta_{3} \mathrm{X}_{3}+\beta_{4} \mathrm{X}_{4}+\beta_{5} \mathrm{X}_{5}+\beta_{6} \mathrm{X}_{6}+\beta_{7} \mathrm{X}_{7} \\
+\quad & \beta_{8} \mathrm{X}_{8}+\mathrm{E}_{\mathrm{i}}
\end{array}
$$

Where,

$\mathrm{P}_{\mathrm{i}}$ is the probability of adoption and non-adoption of hydroponic fodder production technology, $\mathrm{P}_{\mathrm{i}}=1$ indicates adoption and $\mathrm{P}_{\mathrm{i}}=0$ indicates non-adoption.

Dependent variable: Adoption of hydroponic fodder production technology

$$
\text { (Adopters }=1 \text {, otherwise } 0 \text { ) }
$$

$\mathrm{K}_{\mathrm{i}}=$ Probability of adoption of hydroponic fodder technology.

Independent variables:

$\mathrm{X}_{1}=$ Household size (no.);

$\mathrm{X}_{2}=$ Educational level of household head (years of schooling);

$\mathrm{X}_{3}=$ Age of household head (years);

$\mathrm{X}_{4}=$ Farm size (ha);

$\mathrm{X}_{5}=$ Annual income $(\mathrm{Tk}$.$) ;$ 
$\mathrm{X}_{6}=$ Farming experience (years of farming);

$\mathrm{X}_{7}=$ Training $\left(\mathrm{P}_{\mathrm{i}}=1\right.$ indicates having training on hydroponic fodder production and $\mathrm{P}_{\mathrm{i}}=0$ indicates having no training on hydroponic fodder production);

$\mathrm{X}_{8}=$ Extension contact $\left(\mathrm{P}_{\mathrm{i}}=1\right.$ indicates having extension contact and

$\mathrm{P}_{\mathrm{i}}=0$ indicates having no extension contact);

$\beta_{0}=$ Intercept;

$\beta_{1}$ to $\beta_{8}=$ Regression coefficients of the independent variables; and

$\mathrm{E}_{\mathrm{i}}=$ Error term.

The marginal probabilities of the key determinants of adopting hydroponic fodder technology were estimated based on expressions derived from the marginal effect of the Logit model which was as follows:

$\mathrm{dK} / \mathrm{dX}=\beta_{\mathrm{i}}\left\{\mathrm{P}_{\mathrm{i}}\left(1-\mathrm{P}_{\mathrm{i}}\right)\right\}$

Where,

$\beta_{\mathrm{i}}=$ Estimated Logit regression coefficient with respect to the $\mathrm{i}^{\text {th }}$ factor; and

$\mathrm{P}_{\mathrm{i}}=$ Estimated probability of farmers' adoption status.

\section{SWOT analysis}

SWOT analysis was done to identify the problems and potentials of hydroponic fodder technology. The SWOT analysis guided to identify the positives and negatives inside of the organization (S-W) and outside of it in the external environment (O-T) (Gürel and Tat, 2017).

\section{Sustainability perspective of hydroponic fodder production technology}

Sustainability describes a condition in which natural systems and social systems survive and thrive together indefinitely. A sustainable condition allows people to meet the needs of the present without compromising the ability of future generations to meet their own needs (IISD, 2015). 4E sustainability framework analysis uses perspectives from energy, environment, economics and equity in social/political aspects to explain how hydroponic fodder production technology contributes to maintain sustainability (Braun, 2017).

\section{Socioeconomic profile of the farmers}

Table 1 represents the basic information of the farmers in the study areas. It is found that average household size of the farmers was 5.0 which was higher than the national average of 4.1 (HIES, 2016); and farm size was 0.48 ha. Average dependency ratio of the farmers (1.8) indicated that on an average, about 2 household members were dependent on the economically working and earning person of that household. The percentages of male and female respondents were 64.2 and 35.8, 
respectively in the study areas. Average age of the farmers was found to be 39 years. Majority of the farmers completed at least primary and above educational level (47.5\% farmers).

Table 1. Basic information about the selected farmers

\begin{tabular}{lcc}
\hline Particulars & & Respective information \\
\hline Average household size (no.) & & 5.0 \\
\hline Average farm size (ha) & & 0.48 \\
Average dependency ratio (no.) & & 1.8 \\
Average sex distribution & Male & 64.2 \\
(\% of farmers) & Female & 35.8 \\
Average age (years) & & 39 \\
& Illiterate & 18.3 \\
Literacy rate (\% of farmers) & Sign only & 34.2 \\
& Primary and above & 47.5 \\
Occupational status & Agriculture only & 31.7 \\
(\% of farmers) & Agriculture and others & 68.3 \\
& Farm income & $51793(56.1 \%$ of total income) \\
Average annual income (Tk.) & Non-farm income & $40519(43.9 \%$ of total income) \\
& Total income & 92312 \\
\hline
\end{tabular}

Source: Field survey, 2018.

Most of the farmers (68.3\% farmers) were engaged in agriculture as well as other income generating activities like labour selling, service, small business, etc. It is also shown that average annual income of the farmers was Tk. 92312, of which 56.1\% income was from farming activities (i.e. income from crop, livestock, poultry, homestead and agro-forestry) and $43.9 \%$ income was from non-farming activities (i.e. income from small business, wage labour, shop keeping, van/rickshaw pulling and other sources) (Table 1).

\section{Adopter categories}

It is evident from table 2 that in the case of adopting an innovation like hydroponic fodder technology, the percentages of innovators were $5.0 \%$, early adopters were $15.8 \%$, early majority were $29.2 \%$, late majority were $35.8 \%$ and laggards were $14.2 \%$. Though majority of the farmers were pessimistic about this fodder farming technology at the beginning, the adoption of this technology was ultimately successful. The result is similar with Uddin et al. (2017) where the authors revealed that in the case of adopting an innovation like conservation agriculture, majority of the farmers were within the late majority category. 
Table 2. Trend of adopting hydroponic fodder technology

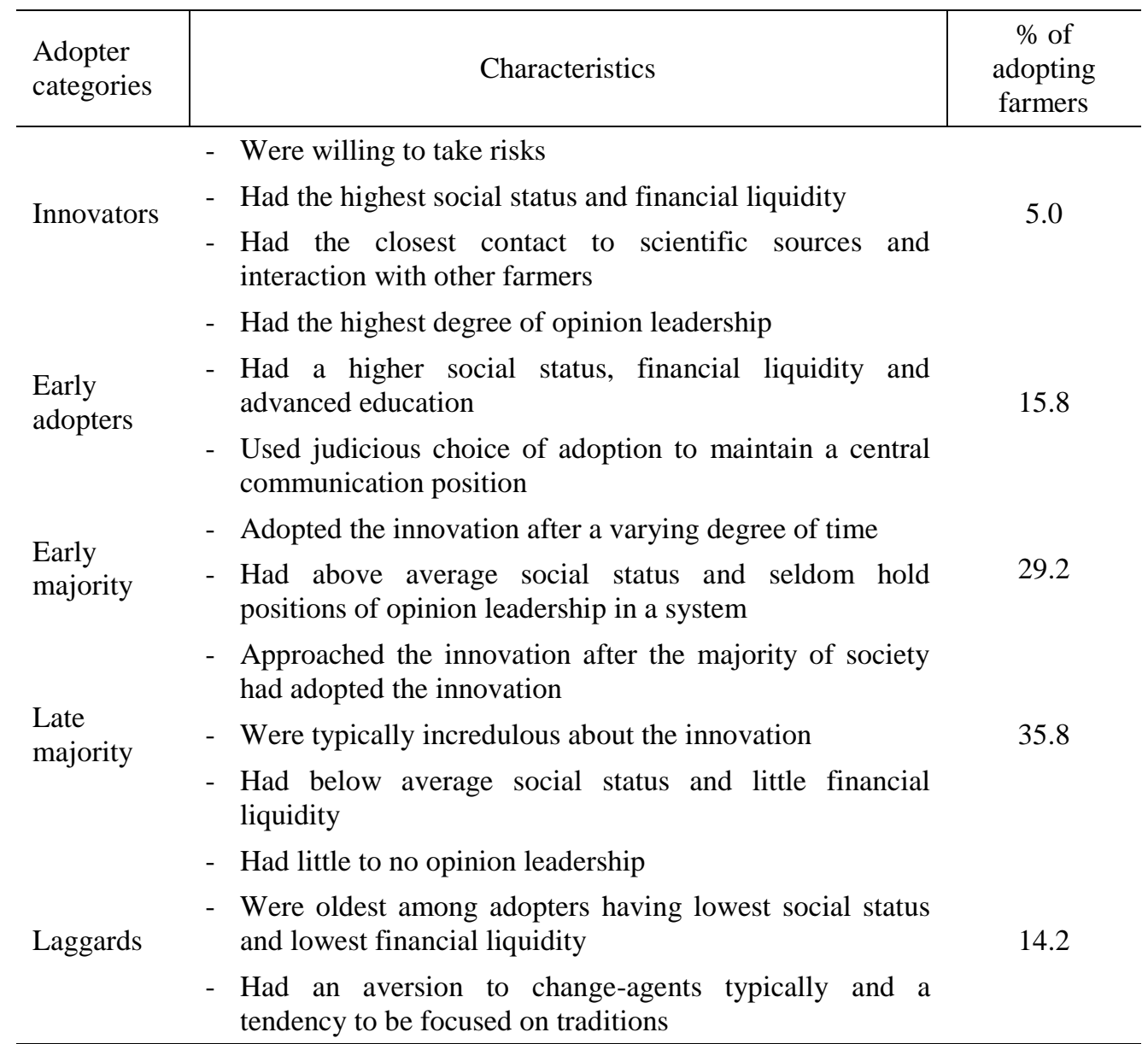

Source: Field survey, 2018.

\section{Profitability of hydroponic fodder production}

Profitability of hydroponic fodder production was measured in terms of gross return, gross margin, net return and benefit cost ratio. Variable and fixed costs were taken into deliberation to estimate the total cost of production. Variable costs included human labour, seed, tray and other equipments, and watering; and fixed cost included land use cost and depreciation cost of equipments and shed. It is seen from table 3 that total variable cost was Tk.3900 and total fixed cost was Tk.2700 per decimal, respectively. Total cost of hydroponic fodder production was estimated at Tk. 6600 per decimal, of which 36.4 and 34.8 percent of total cost were incurred as for seed purchasing and depreciation cost, respectively. Table 3 also represents that gross return from hydroponic fodder production was Tk.12000 per decimal. Gross margin 
and net return were estimated at Tk.8100 and Tk.5400 per decimal, respectively. BCR of hydroponic fodder production was found to be 1.82 which implied that by investing Tk.100 per decimal in hydroponic fodder production, farmers received Tk. 182 in return. The study was slightly similar with Islam et al. (2013) where the authors revealed that the BCRs for fodder producers cum sellers were higher than the producers in all of the study areas of Bangladesh.

Table 3. Profitability of hydroponic fodder production

Cost of hydroponic fodder production

$\begin{array}{lcc}\text { Particulars } & \text { Tk. decimal }^{-1} & \text { Percentage (\%) of total cost } \\ \text { Variable costs } & & \\ \text { Human labour } & 300 & 4.5 \\ \text { Seed } & 2400 & 36.4 \\ \text { Tray and other equipments } & 900 & 13.6 \\ \text { Watering } & 300 & 4.5 \\ \text { i. Total variable cost } & 3900 & 59.0 \\ \text { Fixed costs } & & \\ \text { Land use cost } & 200 & 3.1 \\ \text { Depreciation cost } & 2300 & 34.8 \\ \text { Interest on operating capital } & 200 & 3.1 \\ \text { ii. Total fixed cost } & 2700 & 41.0 \\ \text { iii. Total cost } & 6600 & 100.0\end{array}$

Return from hydroponic fodder production

$\begin{array}{lccc}\text { Particulars } & \begin{array}{c}\text { Quantity } \\ \left(\mathrm{kg} \mathrm{decimal}^{-1}\right)\end{array} & \begin{array}{c}\text { Price } \\ \left(\mathrm{Tk}^{-1} \mathrm{~kg}^{-1}\right)\end{array} & \begin{array}{c}\text { Amount of } \\ \text { return }(\mathrm{Tk} . \\ \left.\mathrm{decimal}^{-1}\right)\end{array} \\ \text { iv. Gross return } & 600 & 20 & 12000 \\ \text { v. Gross margin (iv - i) } & & & 8100 \\ \text { vi. Net return (iv - iii) } & & & 5400 \\ \text { vii. Benefit cost ratio (BCR) (iv } \div \text { iii) } & & & 1.82\end{array}$

Source: Authors' estimation, 2018.

\section{Factors influencing adoption of hydroponic fodder technology by the farmers}

A Logit model was used to identify the factors influencing adoption of hydroponic fodder production technology by the farmers. In this study, eight independent variables were identified as major determinants of adopting this technology by the farmers. Four out of eight independent variables included in the model were found 
significant in explaining the variation in adopting hydroponic fodder production technology by the farmers. These variables were farm size, farming experience, training and extension contact (Table 4).

Table 4. Estimated values of coefficients and marginal effects of logit model

\begin{tabular}{lccccc}
\hline Explanatory variables & Coefficients & Standard errors & p-value & $\mathrm{dK} / \mathrm{dX}$ \\
\hline Intercept & 3.810 & 1.356 & 0.325 & - \\
Household size $\left(\mathrm{X}_{1}\right)$ & -0.211 & 0.132 & 0.214 & -0.003 \\
Educational level of household head $\left(\mathrm{X}_{2}\right)$ & 0.060 & 0.195 & 0.110 & 0.009 \\
Age of household head $\left(\mathrm{X}_{3}\right)$ & -0.195 & 0.075 & 0.164 & -0.008 \\
Farm size $\left(\mathrm{X}_{4}\right)$ & $0.006^{*}$ & 0.096 & 0.063 & 0.013 \\
Annual income $\left(\mathrm{X}_{5}\right)$ & 0.690 & 0.183 & 0.337 & 0.013 \\
Farming experience $\left(\mathrm{X}_{6}\right)$ & $0.039^{* *}$ & 0.121 & 0.029 & 0.006 \\
Training $\left(\mathrm{X}_{7}\right)$ & $0.123^{* * *}$ & 0.044 & 0.000 & 0.010 \\
Extension contact $\left(\mathrm{X}_{8}\right)$ & $0.179^{*}$ & 0.127 & 0.092 & 0.008 \\
\hline
\end{tabular}

Source: Authors' estimation, 2018.

Note: $* * *, * *$ and $*$ indicate significant at $1 \%, 5 \%$ and $10 \%$ probability level, respectively.

The coefficient estimates of Logit model revealed that educational level of household head, farm size, annual income, farming experience, training and extension contact had positive impact; and household size and age of household head had negative impact on farmers' hydroponic fodder technology adoption. The significant variables found from the model were farm size, farming experience, training and extension contact (significant at 10, 5, 1 and $10 \%$ probability level, respectively).

The marginal effect estimates indicated that if educational level of household head, farm size, farmers' annual income, experience of farming, training on this technology, and extension contact with government and non-government extension agents are increased by 1 unit, farmers' probability of adopting hydroponic fodder production technology will be increased by $0.009,0.013,0.013,0.006,0.010$ and 0.008 percent, respectively, holding other factors constant. On the contrary, if household size of the farmers and age of household head are increased by 1 unit, farmers' probability of adopting hydroponic fodder production technology will be decreased, keeping other factors the same (Table 4). Njima (2016) supported the findings slightly where the author showed that farmers' number of dependants and access to information through seminars and internet were the factors influencing hydroponics fodder production among the smallholder dairy farmers in Kenya. 


\section{SWOT analysis on hydroponic fodder production technology}

SWOT analysis on hydroponic fodder production technology is shown in table 5. In terms of strengths, $80.0 \%$ farmers stated that fodder produced by hydroponic technology was more nutritive compared to field grass for adequacy of fermentable carbohydrates, protein, minerals and vitamins. Unlike field grass production system that use run-to-waste irrigation practices, water spraying and recirculation system could be used in hydroponic fodder technology for reducing the amount of waste water.

Table 5. SWOT analysis matrix

\begin{tabular}{|c|c|c|c|c|c|c|c|}
\hline \multicolumn{3}{|c|}{ Statements } & \multirow{2}{*}{$\begin{array}{c}\% \text { of } \\
\text { farmers } \\
80.0\end{array}$} & \multicolumn{3}{|r|}{ Statements } & \multirow{2}{*}{$\begin{array}{c}\% \text { of } \\
\text { farmers } \\
87.5\end{array}$} \\
\hline \multirow{3}{*}{ 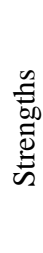 } & i) & $\begin{array}{l}\text { More nutritive than field } \\
\text { grass }\end{array}$ & & \multirow{3}{*}{ 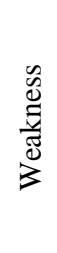 } & i) & $\begin{array}{l}\text { High installation cost for } \\
\text { production }\end{array}$ & \\
\hline & ii) & $\begin{array}{l}\text { Less requirement of water } \\
\text { for fodder production }\end{array}$ & 78.3 & & ii) & $\begin{array}{l}\text { Unavailability and higher price } \\
\text { of seed }\end{array}$ & 72.5 \\
\hline & iii) & $\begin{array}{l}\text { Less labour and maintenance } \\
\text { cost }\end{array}$ & 54.2 & & iii) & Applicable in low temperature & 59.7 \\
\hline \multirow{3}{*}{$\begin{array}{l}\stackrel{\mathscr{U}}{\Xi} \\
\stackrel{\Xi}{\Xi} \\
\stackrel{0}{0} \\
\stackrel{0}{0} \\
0\end{array}$} & i) & $\begin{array}{l}\text { Can be used in places where } \\
\text { in-ground fodder production } \\
\text { is not possible }\end{array}$ & 69.2 & \multirow{3}{*}{$\underset{\overparen{D}}{\stackrel{\mathscr{E}}{E}}$} & i) & $\begin{array}{l}\text { Sensitive to temperature and } \\
\text { humidity }\end{array}$ & 91.8 \\
\hline & ii) & $\begin{array}{l}\text { High consumer demand for } \\
\text { being organic }\end{array}$ & 82.5 & & ii) & $\begin{array}{l}\text { Fungus affected fodder is less } \\
\text { digestive }\end{array}$ & 41.7 \\
\hline & iii) & $\begin{array}{l}\text { Can be used as medicine for } \\
\text { human high blood pressure } \\
\text { and cardiac diseases }\end{array}$ & 95.8 & & iii) & $\begin{array}{l}\text { Cannot be stored for a longer } \\
\text { time }\end{array}$ & 61.7 \\
\hline
\end{tabular}

Source: Field survey, 2018.

According to $78.3 \%$ farmers, hydroponic fodder technology requires nearly $4 \%$ of that water used under field conditions to produce the same amount of fodder. The technology was also appreciated by $54.2 \%$ farmers for its less labour requirement and lower maintenance cost. The major weakness that farmers faced was the high initial capital investment (stated by $87.5 \%$ farmers). They had to invest a big amount of money to acquire production trays, seeds, equipments and construct a production house. Another major weakness was availability and price of seed (according to $72.5 \%$ farmers). It was found that availability of seed was sparse in the market and so, respective price of seed was very high (Table 5).

The biggest opportunity of hydroponic fodder was its use for dual purpose, i.e., for livestock feeding as well as human consumption. Majority of the farmers confirmed that this fodder was highly consumed by the people because of its medicinal value to cure blood pressure and cardiac diseases, and had high demand for livestock feeding as no fertilizer, herbicide or pesticide was used to produce the grass. This technique 
was useful to produce fodder in the areas where there was shortage of grazing land or the land was not suitable for grass production (opined by $69.2 \%$ farmers). More than $91 \%$ farmers opined that hydroponic fodder was highly sensitive to room temperature and humidity, which was identified as the major threat for this fodder production technology. Failure to control temperature and humidity could cause to grow mold, fungi and bacteria to develop. Farmers (41.7\%) reported that if fungus affected fodder would fed to the livestock, it could create digestion problem to livestock and in case of extreme level, the livestock could result in a death. About two third farmers stated that hydroponic fodder was highly perishable in nature (Table 5). Mehta and Sharma (2016) also found some advantages and disadvantages of hydroponic fodder production technology which are partly supportive with this SWOT analysis.

\section{Sustainability of hydroponic fodder production technology}

Sustainability of hydroponic fodder production technology is confirmed when the physical development and institutional operating practices of this technology meet the needs of present users and consumers without compromising the ability of future generations to meet their own needs. In this regard, the authors had developed a 4E sustainability framework (Table 6) and explained the sustainability of this technology from the perspectives of energy, environment, economics and equity. The framework is represented and explained as follows:

Table 6. 4E sustainability framework on hydroponic fodder production technology

\begin{tabular}{|c|c|c|}
\hline $\begin{array}{l}\text { Sustainability } \\
\text { perspectives }\end{array}$ & Sustainability determinants & Determining responses \\
\hline \multirow[t]{3}{*}{ Energy } & $\begin{array}{l}\text { Which sources of energy } \\
\text { does hydroponic fodder } \\
\text { production technology } \\
\text { use? }\end{array}$ & $\begin{array}{l}\text { Generally no external energy is used, but } \\
\text { sometimes temperature controller is } \\
\text { incorporated in the production house }\end{array}$ \\
\hline & $\begin{array}{l}\text { Are the energy sources } \\
\text { polluting? }\end{array}$ & No, the energy source is not polluting \\
\hline & $\begin{array}{l}\text { What is the impact of } \\
\text { energy use? }\end{array}$ & $\begin{array}{l}\text { The temperature controller is used in some } \\
\text { production houses for determining the } \\
\text { optimum seed germination temperature }\end{array}$ \\
\hline \multirow[t]{2}{*}{ Environment } & $\begin{array}{l}\text { Does hydroponic fodder } \\
\text { production technology } \\
\text { harm the environment? }\end{array}$ & $\begin{array}{l}\text { No, the technology is friendly to the } \\
\text { environment and ecology }\end{array}$ \\
\hline & $\begin{array}{l}\text { Does the technology or its } \\
\text { applications impact } \\
\text { negative to the consumers? }\end{array}$ & $\begin{array}{l}\text { Hydroponic fodder production technology } \\
\text { prohibits the use of all chemical fertilizers, } \\
\text { pesticides and medicines. So, the } \\
\text { consumption of fodder is safe to the } \\
\text { consumers }\end{array}$ \\
\hline Economics & What are the inputs used in & The major variable inputs are seed, tray \\
\hline
\end{tabular}




\begin{tabular}{|c|c|c|}
\hline $\begin{array}{l}\text { Sustainability } \\
\text { perspectives }\end{array}$ & Sustainability determinants & Determining responses \\
\hline \multirow{6}{*}{$\begin{array}{l}\text { Equity } \\
\text { (social/political) }\end{array}$} & $\begin{array}{l}\text { hydroponic fodder } \\
\text { production? Are they } \\
\text { available? }\end{array}$ & $\begin{array}{l}\text { and watering equipments, and fixed input } \\
\text { is production house. The major challenge } \\
\text { in this case is the availability of seed in } \\
\text { the market }\end{array}$ \\
\hline & $\begin{array}{l}\text { Is the technology } \\
\text { profitable? }\end{array}$ & $\begin{array}{l}\text { Yes, the technology is profitable likely } \\
\text { field grass production }\end{array}$ \\
\hline & $\begin{array}{l}\text { How much profit does the } \\
\text { technology gain? }\end{array}$ & $\begin{array}{l}\text { The return is almost double in terms of } \\
\text { investment }\end{array}$ \\
\hline & Who are the beneficiaries? & The producers as well as the consumers \\
\hline & $\begin{array}{l}\text { How hydroponic fodder } \\
\text { production technology can } \\
\text { contribute to social or } \\
\text { political inequalities? }\end{array}$ & $\begin{array}{l}\text { Now-a-days, a number of women } \\
\text { entrepreneurs are getting involved in this } \\
\text { technology of fodder production. Thus, } \\
\text { gender inequality is lessened }\end{array}$ \\
\hline & $\begin{array}{l}\text { What is the impact of this } \\
\text { technology on } \\
\text { stakeholders' livelihood? }\end{array}$ & $\begin{array}{l}\text { Involvement in hydroponic fodder } \\
\text { production creates scope for employment, } \\
\text { income generation and poverty reduction } \\
\text { in some extent }\end{array}$ \\
\hline
\end{tabular}

Source: Authors' observation, 2018.

Sayara et al. (2016) supported the findings where the authors stated that hydroponic and aquaponic systems are essential for sustainable agriculture and environment in Palestine.

\section{CONCLUSIONS AND POLICY RECOMMENDATIONS}

The study comes to an end with a conclusion that hydroponic fodder production technology as a new fodder production system was cherished highly and adopted successfully by the farmers. The production of hydroponic fodder was highly profitable in the study areas. Farm size, farming experience, training and extension contact had significant impact on adoption of hydroponic fodder production technology by the farmers. The nutritional quality of fodder, high start up cost, medicinal value for human consumption and less digestive capability as the major strength, weakness, opportunity and threat of hydroponic fodder. Hydroponic fodder production technology is sustainable from the perspectives of energy, environment, economics and equity. Considering the findings of the study, some policy recommendations have been arisen which are: input support (especially seed), motivation and extension services of government as well as non-government organizations should be properly implemented to raise farmers' awareness about adopting hydroponic fodder production technology. This technology of fodder production is considerably appropriate in town areas and in water logging areas. So, initiative for scientific and technical training programmes should be arranged so that 
farmers' can get inspiration for moving into this new dimension of fodder production technology.

\section{ACKNOWLEDGEMENT}

The authors are thankful to Ministry of Science and Technology (MoST), Government of the People's Republic of Bangladesh for funding to conduct this study. The authors are also grateful to the officials of Bangladesh Rural Advancement Committee (BRAC) for their contribution in selection of sample farmers.

\section{REFERENCES}

Al-Karaki, G.N., and Al-Hashimi, N.(2012).Green fodder production and water use efficiency of some forage crops under hydroponic conditions. ISRN Agronomy, ID: 924672, doi:10.5402/2012/924672.

BBS, (2015).Statistical Yearbook of Bangladesh, Bangladesh Bureau of Statistics, Statistics Division, Ministry of Planning, Government of the People's Republic of Bangladesh, Dhaka.

Braun,D.B.(2017).4Esustainability analysis. Available at https://courseware.ee.calpoly.edu/ db raun/courses/4E-SustainabilityAnalysis.html (accessed on 13 March 2018).

Dillon, J.L., and Hardaker, J.B.(1993).Farm management research for small farmer development, FAO, Rome.

Gujarati, D.N. (2003). Basic econometrics. McGraw-Hill, New York.

Gürel, E., and Tat, M. (2017).SWOT analysis: A theoretical review. The Journal of International Social Research, 10 (51). Available at https://www.researchgate.net/publication/3193677

88_SWOT_ANALYSIS_A_THEORETICAL_REVIEW (accessed on 16 March 2018).

HIES. (2016). Preliminary report on household income and expenditure survey, Bureau of Statistics Division, Ministry of Planning, Government of the People's Republic of Bangladesh, Dhaka.

IISD. (2015). International Institute for Sustainable Development, Winnipeg, Canada.

Islam, R., Jalal, N., and Akbar, M.A. (2016). Effect of seed rate and water level on production and chemical analysis of hydroponic fodder. European Academic Research, 4 (8), 724 6753.

Islam, S., Begum, J., Sarker, N.R., and Khatun, M. (2013).Cost-return analysis of fodder production in selected areas of Bangladesh. Bangladesh Journal of Livestock Research, 20 (1\&2), 54-67.

Jemimah, R., Gnanaraj, P.T., and Muthuramalingam, T. (2015).Hydroponic green fodder production - TANUVAS experience, Tamil Nadu Veterinary and Animal Sciences University, Chenani, India. 
Mehta, M.P., and Sharma, A. (2016).Hydroponic fodder production technology. Benison Media. Available at http://benisonmedia.com/hydroponic-fooder-productiontechnology/ (accessed on 19 April 2018).

Migwi, P.K. (1997).Improving the nutritive value of low quality roughage for ruminants by ensiling with citrus pulp and poultry litter. Unpublished Master of Science thesis, Department of Animal Science, University of Adelaide, Australia.

Naik, P.K., Gaikwad, S.P., Gupta, M.J., Dhuri, R.B., Dhumal, G.M., and Singh, N.P. (2013). Low cost devices for hydroponics fodder production. Available at https://www.researchg ate.net/profile/Mathala_Gupta/publication/258241382 (accessed on 05 January 2018).

Njima, P.M. (2016).An assessment of factors influencing production of hydroponics fodder among smallholder dairy farmers in Kiambu sub county, Kenya. A research project report submitted in partial fulfilment for the requirements of the award of the degree of Master of Arts in Project Planning and Management, University of Nairobi, Kenya.

Pramanik, M.A. (2017).Bangladesh research council equipping farmers with Hydroponic fodder system. Available at http://bdnews24.com/business/2017/03/30 (accessed on 21 January 2018).

Saha, S.K. (2010).Soilless cultivation for landless people: An alternative livelihood practice through indigenous hydroponic agriculture in flood-prone Bangladesh. Ritsumeikan Asia Pacific University, Beppu, Japan.

Salam, M.A., Jahan, N., Hashem, S., and Rana, K.M.S.(2014).Feasibility of tomato production in aquaponic system using different substrates. Progressive Agriculture, 25, 54-62.

Sayara, T., Amarneh, B., Saleh, T., Aslan, K., Abuhanish, R., and Jawabreh, A. (2016). Hydroponic and aquaponic systems for sustainable agriculture and environment. International Journal of Plant Science and Ecology, 2(3), 23-29.

Uddin, M.T., Dhar, A.R., and Rahman, M.H. (2017).Improving farmers' income and soil environmental quality through conservation agriculture practice in Bangladesh. American Journal of Agricultural and Biological Sciences, 12(1), 55-65.

UNB. (2017).United News of Bangladesh. Amazing Grass! The Daily Star. Available at http://www.thedailystar.net/frontpage/amazing-grass-1380580 (accessed on 19 February 2018). 